\title{
Respuesta de IFN- $\gamma$ e IL-4 en ratones inoculados con una proteína $G$ recombinante del virus de la rabia
}

\author{
Response of IFN- $\gamma$ and IL-4 in mice inoculated with \\ rabies virus recombinant $G$ protein
}

\author{
Edith Rojas-Anayaa, Fernando Esquivel-Guadarramab, Estela Escribano-Romerob, Ana \\ Belén Blázquezc, Graciela Tapia Pérezd, Lilia Soto Ruízd, Elizabeth Loza-Rubioa
}

\begin{abstract}
RESUMEN
El objetivo de este estudio fue comparar el comportamiento de IFN- $\gamma$ e IL-4 en ratones inoculados con proteína G recombinante del virus de la rabia, que se expresa en maíz transgénico o baculovirus. Para este propósito, grupos de ratones se inocularon de la siguiente manera: Grupo 1, vacuna contra el virus de la rabia inactivado vía im; Grupo 2, proteína G recombinante derivada de plantas por vía oral; Grupo 3, proteína G expresada en baculovirus vía im; Grupo 4, proteína G expresada en baculovirus por vía oral; Grupo 5, maíz no transformado por vía oral. Los niveles de IFN- $\gamma$ e I L-4 y los anticuerpos específicos se evaluaron cada 15 días. El desafío se realizó a los 60 días post inoculación (pi). Los grupos 1 y 3 promovieron una mejor respuesta humoral. Por otro lado, los resultados mostraron que los mismos grupos mostraron los mejores niveles de IFN- $\gamma$ en el día 10 pi; mientras que la IL-4 se detectó en el día 15 pi. Para el estudio de supenvivencia, el $83 \%$ de los ratones inmunizados con vacuna inactivada, maíz y los inoculados im con extractos de baculovirus sobrevivieron la infección viral. La proteína G de la rabia recombinante expresada en baculovirus promovió IFN- $\gamma$ y los anticuerpos de una manera similar a la vacuna de rabia inactivada. A pesar de esto los ratones alimentados con maíz transgénico sobrevivieron al desafío en el mismo porcentaje que el grupo 3.
\end{abstract}

PALABRAS CLAVE: Rabia, Baculovirus, Maíz, IFN-g, I L-4.

\begin{abstract}
The aim of this study was to compare the performance of IFN- $\gamma$ and IL-4 in mice inoculated with recombinant rabies virus $G$ protein that was expressed either in transgenic maize or baculovirus. For this purpose, groups of mice were inoculated as follows: Group 1, inactivated rabies vaccine im; Group 2, plant-derived recombinant G protein orally; Group 3, baculovirus-expressed G protein im; Group 4, baculovirus-expressed G protein orally; and group 5, untransformed maize orally. The levels of IFN- $\gamma$ and IL-4 and specific antibodies were evaluated every $15 \mathrm{~d}$. A challenge was performed at d 60 post-inoculation (pi). Groups 1 and 3 promoted the best humoral response. On the other hand, the results showed that the same groups showed the best levels of IFN- $\gamma$ at d 10 pi; while the pick of I L4 was detected at d 15 pi. For the survival study, $83 \%$ of the mice immunized with inactivated vaccine, maize or im baculovirus extracts survived viral infection. The recombinant rabies $G$ protein expressed in baculovirus promoted IFN- $\gamma$ and antibodies in a similar way to the inactivated rabies vaccine. In spite of this, mice fed with transgenic maize survived to the challenge at the same percentage than group 3.
\end{abstract}

KEY WORDS: Rabies, Baculovirus, Maize, I FN-g, I L-4.

Recibido el 6 de enero de 2015. Aceptado el 18 de marzo de 2015.

a Centro Nacional de Investigaciones Disciplinarias en Microbiología Animal (CENID-MA), INIFAP, México D,F. México. eli_rubio33@hotmail.com, loza.elizabeth@inifap.gob.mx. Correspondencia al último autor.

b Universidad Autónoma de Morelos, Cuernavaca, Morelos, México.

c Departamento de Biotecnología. INIA. Madrid, España.

d Departamento de Genética y Bioestadística. FMVZ-UNAM. México. 


\section{INTRODUCCIÓN}

Un gran número de las vacunas contra la rabia se han desarrollado utilizando diferentes sistemas, incluyendo baculovirus y plantas(1-7). Una de las principales ventajas del sistema de expresión de células de insecto-baculovirus es el alto rendimiento de la proteína recombinante producida por litro de cultivo celular(8). Aunque se ha informado de la expresión de la proteína $\mathrm{G}$ del virus de la rabia en diferentes sistemas vegetales $(7,9)$ el desarrollo de una vacuna oral contra la rabia reduciendo el costo de producción y distribución sería muy útil, especialmente para los países en desarrollo, donde la enfermedad es endémica en humanos y animales domésticos. La glicoproteína es el antígeno principal del virus de la rabia, es una proteína transmembrana, que consiste en un dominio citoplásmico, un dominio transmembranal y un ectodominio expuesto como trimero. El ectodominio está involucrado en la inducción de anticuerpos neutralizantes y linfocitos T citotóxicos y cooperadores $(10,11)$. Muchos estudios han demostrado que los extractos crudos del antígeno recombinante purificado de los extractos puros de las plantas o la planta entera pueden inducir respuestas inmunes locales o sistémicas $(1,7,12)$. En la literatura existen pocos estudios que han evaluado el tipo de citocinas inducidas por las vacunas antirrábicas de nueva generación(13).

El objetivo de este estudio fue comparar la respuesta de IFN- $\gamma$ e IL-4 en ratones inoculados con proteína $\mathrm{G}$ recombinante del virus de la rabia ( $r$ GpRV) que se expresó tanto en células de insecto infectadas con baculovirus como en maíz transgénico. Para este propósito, la transformación y regeneración de plantas de maíz para la producción de maíz transgénico utilizado para la inmunización se realizó como se ha descrito previamente por Loza-Rubio et al(14).

\section{MATERIALES Y MÉTODOS}

Proteínas recombinantes

Para baculovirus recombinante, el fragmento que codifica la glicoproteína soluble de virus de la

\section{INTRODUCTION}

A large number of the anti-rabies vaccines have been developed using different systems, including baculovirus and plants(1-7). One of the major advantages of the baculovirus-insect cell expression system is the high yield of recombinant protein produced per liter of cell culture(8). Although the expression of the rabies virus $\mathrm{G}$ protein in different plant systems has been reported $(7,9)$ the development of an oral rabies vaccine that has a reduced cost of production and distribution will be very useful, especially for developing countries where the disease is endemic in humans and domestic animals. Glycoprotein is the main antigen of rabies virus, it is a transmembrane protein, consisting of a cytoplasmic domain, a transmembrane domain and an ectodomain exposed as trimmers. The ectodomain is involved in the induction of neutralizing antibodies and cytotoxic and helper $\mathrm{T}$ Iymphocytes $(10,11)$. Many studies have demonstrated that crude extracts, purified recombinant antigen expressed in plants, or the whole plant can induce local or systemic immune responses $(1,7,12)$. In the literature there are few studies that have evaluated the type of cytokines induced by new generation rabies vaccines(13).

The aim of this study was to compare the response of IFN- $\gamma$ and IL-4 in mice inoculated with recombinant rabies virus $\mathrm{G}$ protein ( $\mathrm{rGpRV}$ ) that was expressed either in transgenic maize or baculovirus-infected insect cells. For this propose the transformation and regeneration of maize plants for the production of the transgenic corn used for immunization was performed as described previously(14).

\section{MATERIALS AND METHODS}

Recombinant proteins

While for recombinant baculovirus, the fragment encoding the soluble glycoprotein of rabies virus was amplified by RT-PCR. (SuperScript TM OneStep RT-PCR, Invitrogen, Carlsbad, CA, USA) using a haematophagous bat CASS-88 strain 
rabia se amplificó por RT-PCR (SuperScriptTM One-Step RT-PCR, Invitrogen, Carlsbad, CA, EE.UU.), utilizando un virus de murciélago hematófago cepa CASS-88. Los iniciadores: 5'GTGTGGATCCTATGAAATTCCCCATC-3 'y 3'-5GAGACTCTAGATCCCCAGTTAGGGAG' (sitios de restricción BamHI y Xbal incluidos en los iniciadores están subrayados) se utilizaron para amplificar el gen G. El producto de PCR se insertó en los sitios Xbal-BamHI del vector digerido pFastBacMel-B2 bajo el control del promotor constitutivo de la polihedrina como se ha descrito previamente(15).

Para la detección de la glicoproteína G recombinante en ambos sistemas de expresión, se realizó una prueba de Western blot utilizando un suero de conejo hiperinmune preparado en nuestro laboratorio(14). Las concentraciones de proteína se determinaron utilizando el método de Bradford (Bio-Rad, EE.UU.) y el nivel de expresión de rGpRV se determinó por densitometría usando una curva estándar de albúmina de suero bovino. Los geles se tiñeron con azul de Coomassie y las señales se digitalizaron y se cuantificaron por análisis Kodak 1D Imagen Software (Kodak Company Este, New Haven, EE.UU.).

\section{Evaluación de la respuesta inmune}

Para evaluar la respuesta inmune, se adquirieron en el Bioterio México (México, DF) ratones CD1 machos de 21 días de edad $(n=90)$ y se mantuvieron en condiciones de limpieza con comida y agua ad libitum. Todos los experimentos con animales se aprobaron y realizaron de acuerdo con las directrices de la Norma Oficial Mexicana NOM-062-ZOO-1999. Los animales se dividieron en cinco grupos: el grupo 1 recibió una dosis intramuscular (im) de vacuna antirrábica inactivada comercial (Derriplus, PRONABIVE, México, DF); en el grupo 2, los ratones se alimentaron con un gramo de granos de maíz que contenían 100 mg de proteína del virus $\mathrm{G}$ de la rabia; el grupo 3 recibió una dosis im de 100 mg de proteína $\mathrm{G}$ recuperada a partir de células de insecto virus. The primers: 5'-GTGTGGATCCTATGAAATT CCCCATC-3' and 3'-GAGACTCTAGATCCCCAGTTA GGGAG-5' (BamHI and Xbal restriction sites included in the primers are underlined) were used to amplified gene G. The PCR product was inserted into a BamHI and Xbal-digested pFastBacMel-B2 vector under the control of the polyhedrin constitutive promoter as described previously(15).

For the detection of the recombinant $G$ glycoprotein in both expression systems, it was performed a Western blot using a hyper-immune rabbit serum prepared in our laboratory(14). Protein concentrations were determined using the Bradford method (Bio-Rad, USA) and the expression level of rGpRV was determined by densitometry using a standard curve of bovine serum albumin. Gels were stained with Coomassie blue and the signals were scanned and quantified by Kodak 1D Image Analysis Software (East Kodak Company, New Haven, USA).

Evaluation of immune response

For evaluating immune response 21-d-old CD1 male mice $(n=90)$ were purchased from Bioterio México (Mexico, DF) and maintained under clean conditions with food and water ad libitum. All animal experiments were approved and performed according to the guidelines of the Mexican Official Standard NOM-062-ZOO-1999. Animals were divided into five groups: Group 1 received an intramuscular (im) dose of commercial inactivated rabies vaccine (Derriplus, Pronabive, México, DF); Group 2, mice were fed one gram of maize seeds that contained $100 \mathrm{mg}$ of rabies virus $\mathrm{G}$ protein; Group 3 received an im dose of $100 \mathrm{mg} \mathrm{G}$ protein recovered from insect cells infected with BacGrabMel; Group 4 mice were orally inoculated with $100 \mathrm{mg} \mathrm{G}$ protein expressed by BacGrabMel; Group 5 mice were fed untransformed maize. The remaining mice were bled before immunization and at 10, 15, 30, 45 and $60 \mathrm{~d}$ post inoculation (dpi) to detect specific anti-G antibodies. At $60 \mathrm{dpi}$, each mouse was 
infectadas con BacGrabMel; en el grupo 4 los ratones se inocularon por vía oral con la proteína G, 100 mg expresada por BacGrabMel; en el grupo 5, los ratones se alimentaron con maíz no transformado. Los ratones restantes se sangraron antes de la inmunización y a los 10, 15, 30, 45 y 60 días post inoculación (dpi) para detectar anticuerpos específicos anti-proteína G. A los 60 dpi, cada ratón se desafió con 106.1 $\mathrm{DL}_{50} / \mathrm{ml}$ de virus de rabia cepa CASS-88. Los animales que presentaron signos de rabia se sacrificaron (15 días), y sus cerebros se retiraron y se realizaron la pruebas de inmunofluorescencia (FAT)(16). Los sueros se evaluaron para detectar anticuerpos neutralizantes de virus de rabia (VNA) mediante la prueba rápida de inhibición de focos fluorescentes (RFFIT, por sus siglas en inglés), como se ha descrito previamente(17).

Respuesta celular

Por otra parte, se usaron 12 ratones de cada grupo para la detección de citocinas. Tres ratones de cada grupo se sacrificaron humanitariamente a los 5, 10, 15 y 20 días después de la inmunización y se retiraron los bazos para evaluar la secreción de citocinas. En primer lugar, se preparó una cinética para determinar el mejor momento para la proliferación de esplenocitos. Por lo anterior, se prepararon suspensiones de esplenocitos y las células muertas se eliminaron utilizando Lympholyte ${ }^{\circledR}$ (Cedarlane, Ontario, Canadá). El tiempo óptimo (72 h) para tomar los sobrenadantes de esplenocitos después de la vacunación de cultivo de bazo se determinó mediante una curva(13). Los sobrenadantes se utilizaron para determinar la presencia de IL-4 e IFN- $\gamma$ usando los kits comerciales ELISA ReadySET-G ELISA (eBioscience, San Diego CA, EE.UU.) según las instrucciones del fabricante. Brevemente, las placas ELISA Maxisorp ${ }^{\circledR}$ se bloquearon incubando a temperatura ambiente durante $1 \mathrm{~h}$. Posteriormente, se recubrieron con $100 \mu \mathrm{l}$ por pozo con anticuerpo de captura y se incubaron durante la noche a $4{ }^{\circ} \mathrm{C}$ y se lavaron tres veces. Los estándares se diluyeron a concentraciones apropiadas y se adicionaron 100 im challenged with $10^{6.1} \mathrm{LD}_{50} / \mathrm{mL}$ of CASS-88 rabies strain. Animals showing signs of rabies were euthanized ( $15 \mathrm{~d}$ ), and their brains were removed and tested for rabies by the fluorescent antibody test (FAT)(16). Sera were tested for rabies virus neutralizing antibody (VNA) titres using the rapid fluorescent focus inhibition test (RFFIT), as previously described(17).

\section{Cellular response}

On the other hand, 12 mice from each group were used for cytokine detection. Three mice from each group were humanely euthanized at 5, 10, 15 and $20 \mathrm{~d}$ after immunization and spleens were removed to measure cytokine secretion. First, a kinetic test was prepared to determine the best time for splenocyte proliferation. Therefore, splenocyte suspensions were prepared and dead cells were removed using Lympholyte ${ }^{\circledR}$ cushion (Cedarlane, Ontario, Canada). The optimum time (72 h) to collect post-vaccination spleen culture supernatants was determined by a time-curve(13). Supernatants were harvested and assayed for the presence of IL-4 and IFN- $\gamma$ using ELISA ReadySET-Go systems (eBioscience, San Diego CA, USA) according to the manufacturer's instructions. Briefly, the Maxisorp ${ }^{\circledR}$ ELISA plates were coated with $100 \mu \mathrm{L} /$ well of capture, incubated overnight at $4{ }^{\circ} \mathrm{C}$ and washed three times. Wells were blocked with assay diluents and incubated at room temperature for $1 \mathrm{~h}$. Standards were diluted at appropriate concentrations adding 100 $\mu \mathrm{L} /$ well of top standard concentration to the appropriate wells. A total of $100 \mu \mathrm{L}$ were added per well of each sample and the plates were incubated at room temperature for $2 \mathrm{~h}$. Subsequently, detection antibody was added. Finally, Avidin-HRP and substrate solution were added and were incubated at room temperature for $15 \mathrm{~min}$. Plates were read at $450 \mathrm{~nm}$.

\section{Statistical analysis}

Repeated analysis of variance (ANOVA) was used to test for differences in all the outcomes among groups receiving different immunizations regimens. The levels of IFN- $\gamma$ and IL-4 were 
$\mu l$ por pozos a un número de pozos apropiados. Se añadieron $100 \mu \mathrm{l}$ por pozo de cada muestra y se incubaron las placas a temperatura ambiente durante $2 \mathrm{~h}$. Posteriormente, se añadió anticuerpo de detección. Finalmente, se añadió el sustrato Avidina-HRP y se incubaron a temperatura ambiente durante $15 \mathrm{~min}$. Las placas se leyeron a $450 \mathrm{~nm}$.

\section{Análisis estadístico}

Se utilizó un análisis repetido de varianza (ANOVA) para probar las diferencias en los resultados entre todos los grupos que recibieron diferentes esquemas de inmunización. Los niveles de IFN- $\gamma$ e IL-4 se analizaron por ANOVA de dos vías con Dunnett y comparaciones múltiples de las medias de Bonferroni. El nivel de significancia utilizado fue 0.05 . Los cálculos estadísticos se realizaron utilizando el paquete estadístico SPSS 19 de IBM ${ }^{\circledR}$.

\section{RESULTADOS}

Los extractos de proteína de plantas transformadas y no transformadas y células Sf9 transfectadas con BacGrabMel se evaluaron por analyzed by two-way ANOVA with Dunnett's and Bonferroni multiple comparisons of means. The level of significance used was 0.05 . Statistical calculations were carried out using IBM's SPSS 19 \& statistical package.

\section{RESULTS}

Transformed and non-transformed plant extract protein and Sf9 cells transfected with BacGrabMel were evaluated by western blot. Immunoassay demonstrated the successful expression of the $65 \mathrm{kDa} \mathrm{G}$ protein monomer (Figure 1). This band was not detectable in negative controls. By densitometry it was determined that one gram of maize contained $50 \mu \mathrm{g}$ of rabies glycoprotein. Meanwhile, using baculovirus it was determined that 2 to $7 \mathrm{mg}$ of recombinant protein could be obtained per litre of supernatant from cells infected with the recombinant baculovirus; IFN- $\gamma$ was detected in the splenocytes of mice from all immunized groups from $5 \mathrm{~d}$ after vaccination until $20 \mathrm{~d}$ post-immunization. The levels of IFN- $\gamma$ were similar in animals immunized with the inactivated vaccine (group 1) to those that were im immunized with the baculovirus-expressed $\mathrm{G}$

Figura 1. Identificación de la proteína del virus $\mathrm{G}$ de la rabia en dos sistemas de expresión eucariotas: baculovirus (A) y maíz (B) de transferencia por Western blot

Figure 1. Western blot identification of the rabies virus $G$ protein in two eukaryotic expression systems: baculovirus (A) and maize (B)
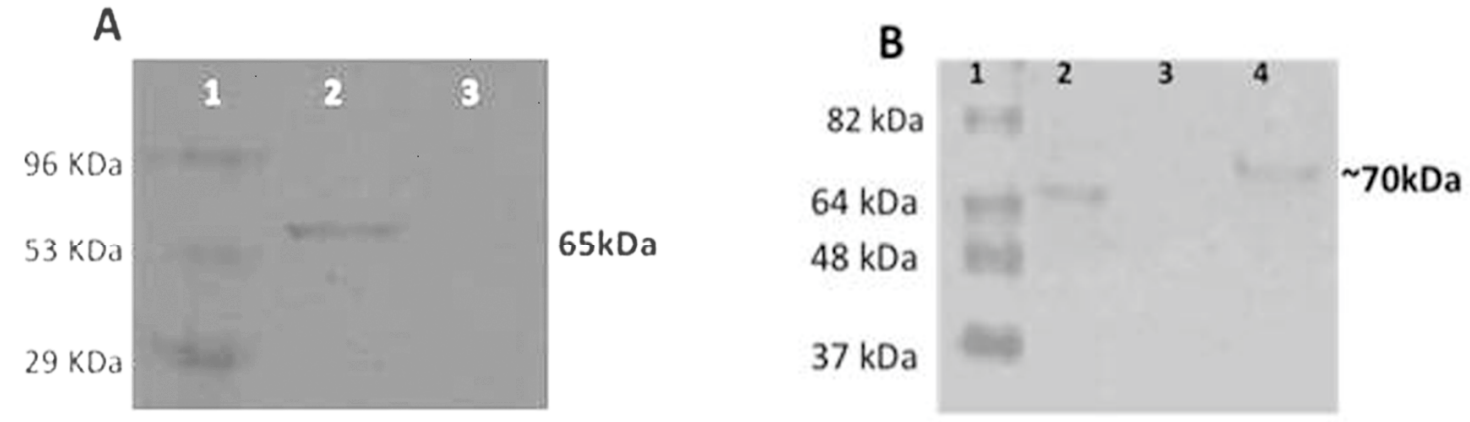

The recombinant glycoprotein was detected in both expression systems. A) Lane 1 molecular weight markers; lane 2 BacGrabMel Sf9 infected cellular extracts; lane 3 Sf9 uninfected cellular extracts. B) Lane 1 molecular weight markers; lane 2 rabies virus G protein purified from BHK-21 cells; lane 3 untransformed maize tissue extracts; lane 4 maize plant tissue extracts transformed with the $\mathrm{G}$ gene. 
Western blot. El inmunoensayo demostró la expresión con éxito del monómero de la proteína $\mathrm{G}$ de $65 \mathrm{kDa}$ (Figura 1). Esta banda no fue detectable en los controles negativos. Por densitometría se determinó que un gramo de maíz contenía 50 ug de glicoproteína de la rabia. Mientras tanto, en baculovirus se determinó que se podrían obtener 2 a $7 \mathrm{mg}$ de proteína recombinante por litro de sobrenadante de células infectadas con el baculovirus recombinante. El IFN- $\gamma$ se detectó en los esplenocitos de los ratones de todos los grupos inmunizados a partir de cinco días después de la vacunación, hasta 20 días después de la inmunización. Los niveles de IFN- $\gamma$ fueron similares en animales inmunizados im con la vacuna inactivada (grupo 1) a los que se inmunizaron con la proteína $G$ expresada en baculovirus (grupo 3) y significativamente mayor $(P<0.01)$ que aquéllos en los grupos inmunizados por vía oral (grupos 2 y 4) (Figura 2A). Asimismo, aunque en menor medida, se observó la inducción de IL-4 en los ratones de todos los grupos inoculados. La concentración máxima de IL-4 se detectó 15 días después de protein (group 3) and significantly higher $(P<0.01)$ than those in the orally immunized groups (groups 2 and 4) (Figure 2A). Likewise, although to a lesser extent, IL-4 induction was also observed in mice from all the inoculated groups. The maximum concentration of IL-4 was detected $15 \mathrm{~d}$ post-immunization, and the levels were similar in all vaccinated animals (Figure 2B). As expected, IFN- $\gamma$ and IL4 were not detected in the control unimmunized mice (group 5).

Figure 3 , shows specific neutralizing antibodies in vaccinated groups, they were detected from 15 dpi until the day of challenge (60 dpi). No specific antibodies were detected in animals from the control group (group 5). Mice in group 3, immunized by the im route with the baculovirus expressed $G$ protein, elicited antibody levels similar to those in group 1 until $30 \mathrm{~d}$ postimmunization. These levels were significantly higher $(P<0.01)$ than those from the other two immunized groups (2 and 4). All (100\%) mice immunized with the inactivated vaccine survived to challenge done at d $60 \mathrm{pi}, 83 \%$ of the mice

Figura 2. A) Niveles de INF- $\gamma$ en ratones inmunizados. B) Cuantificación de IL-4 de citoquinas por ELISA

Figure 2. A) Levels of INF- $\gamma$ in immunized mice. B) Quantification of IL-4 cytokine by ELISA

A

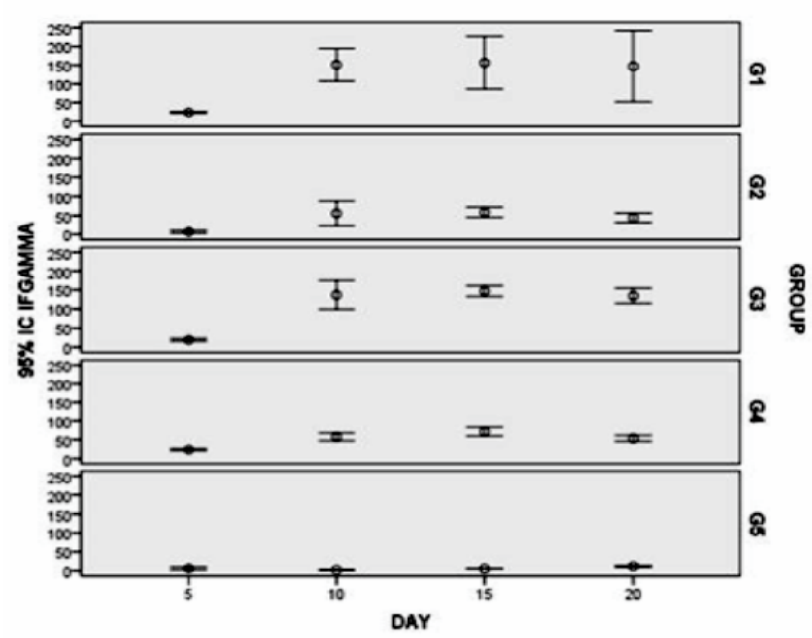

B



Immunized with the inactivated commercial vaccine (G1), maize by the oral route (G2), protein derivate of baculovirus inoculated im (G3), protein derivate of baculovirus by the oral route (G4) and mice fed with untransformed maize (G5). For $\mathrm{INF}_{-\mathrm{y}}$ results are expressed as the means $\pm 95 \%$ I.C. For IL-4 results are expressed as $\mathrm{pg} / \mathrm{ml}(P<0.001)$. 
la inmunización, y los niveles fueron similares en todos los animales vacunados (Figura 2B). Como se esperaba, no se detectaron IFN- $\gamma$ e IL4 en los ratones testigos no inmunizados (grupo 5).

La Figura 3, muestra los anticuerpos neutralizantes específicos en los grupos vacunados, los cuales se detectaron a partir de 15 dpi hasta el día del desafío (60 dpi). No se detectaron anticuerpos específicos en los animales del grupo control (grupo 5). Los ratones en el grupo 3, inmunizado por la vía im con el baculovirus que expresó la proteína G, indujo niveles de anticuerpos similares a los del grupo 1 hasta 30 dpi. Estos niveles fueron significativamente mayores $(P<0.01)$ que los de los otros dos grupos inmunizados (2 y 4). El $100 \%$ de los ratones inmunizados con la vacuna inactivada sobrevivió al desafío en el día 60 pi,

Figura 3. Niveles de anticuerpos neutralizantes inducidos por la glicoproteína de la rabia recombinante ( $\mathrm{G} G \mathrm{pRV}$ ) expresada en diferentes sistemas de expresión

Figure 3. Neutralizing antibody levels induced by recombinant rabies glycoprotein ( $\mathrm{rGpRV}$ ) expressed in different expression systems in mice

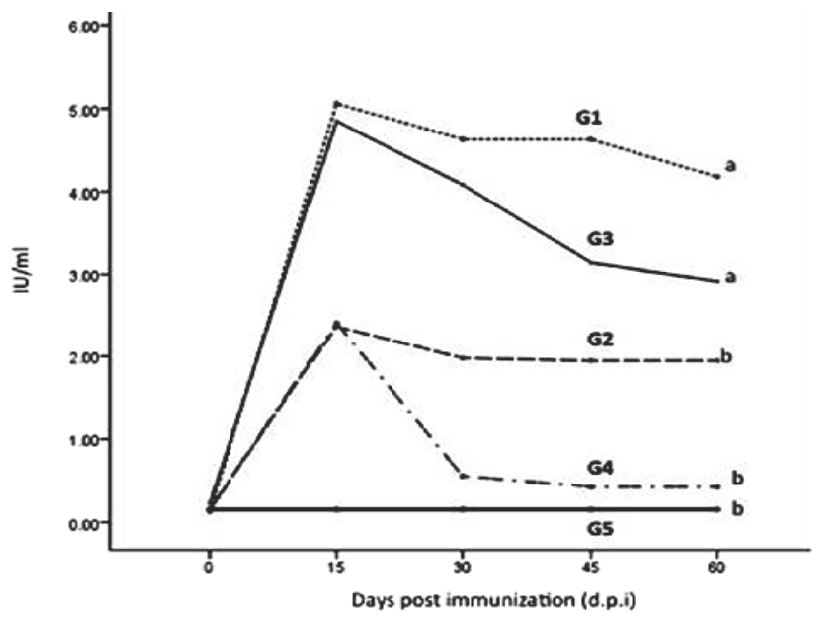

Mice were immunized with inactivated commercial vaccine (G1), maize by the oral route (G2), protein derivate of baculovirus inoculated im (G3), protein derivate of baculovirus by the oral route (G4) and mice fed with untransformed maize (G5). The results are expressed as international units by millilitre $(\mathrm{IU} / \mathrm{ml})$, at different times after immunization $(P<0.01)$. from group 2 (edible plant-derived rGpRV) and group 3 (baculovirus-expressed $\mathrm{G}$ protein administered $\mathrm{im}$ ) survived the infection. In contrast, none of the unvaccinated mice ( $0 \%)$ or those orally inoculated with the recombinant G protein (0\%) were protected (Figure 4). Presence of rabies virus was demonstrated by the FAT test in brains of all dead animals.

\section{DISCUSSION}

Recombinant protein production in mammalian and insect cell lines and transgenic plants and animals are being progressively incorporated into production activities(18). The aim of this study was to analyse the response of IFN- $\gamma$ and IL4 in inoculated mice with rabies virus $G$ protein (GpRV) expressed in baculovirus and maize. In this paper, it was only used the soluble region of the GpRV in order to obtain a soluble protein in the two expression systems. In previous studies it has been shown that the soluble

Figura 4. Tasas de supervivencia de los ratones inmunizados y desafiados con la cepa del virus de la rabia virulenta CASS-88

Figure 4. Survival rates of immunized mice challenged with the virulent CASS-88 rabies virus strain

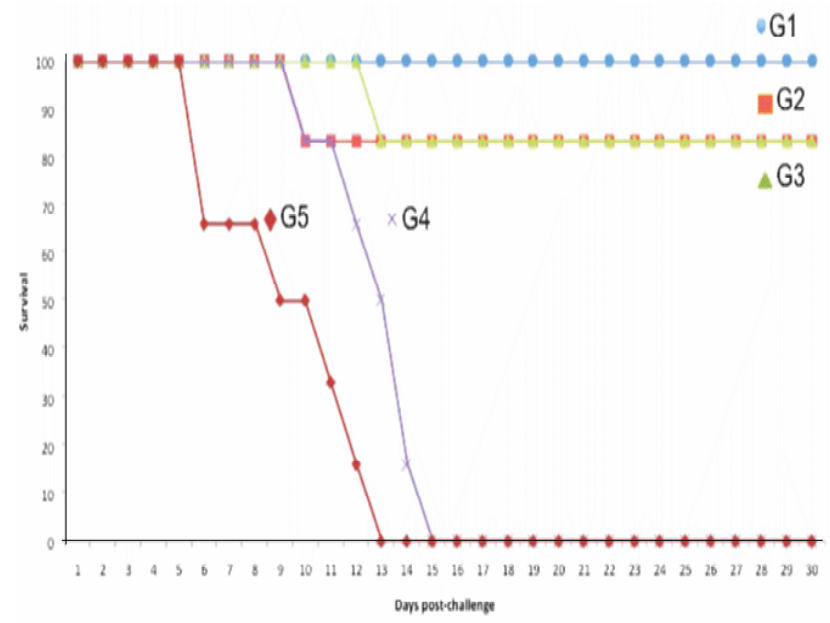

Mice immunized with inactivated commercial vaccine (G1) $100 \%$; maize by the oral route (G2) $88.8 \%$; glycoprotein derivate of baculovirus inoculated im (G3) $88.8 \%$; protein derivate of baculovirus by the oral route (G4) $0 \%$ and mice fed with untransformed maize (G5) $0 \%$. 
$83 \%$ de los ratones del grupo 2 (rGpRV comestible de origen vegetal) y el grupo 3 (expresada en baculovirus proteína G im administrada) sobrevivieron a la infección. En contraste, ninguno de los ratones no vacunados (0\%) o los inoculados por vía oral con la proteína recombinante G (0 \%) fueron protegidos (Figura 4). La presencia de virus de la rabia en los cerebros de todos los animales muertos se demostró por la prueba de inmunofluorescencia directa (FAT, por sus siglas en inglés).

\section{DISCUSIÓN}

La producción de proteínas recombinantes en líneas celulares de mamíferos, insectos y plantas y animales transgénicas se están incorporando progresivamente en las actividades de producción(18). El objetivo de este estudio fue analizar la respuesta de IFN- $\gamma$ e IL4 en ratones inoculados con la proteína $G$ del virus de la rabia (GpRV) expresada en baculovirus y maíz. En este trabajo, sólo se utilizó la región soluble del GpRV con el fin de obtener una proteína soluble en los dos sistemas de expresión. En estudios previos se ha demostrado que la glicoproteína soluble mantiene propiedades antigénicas e inmunogénicas que inducen anticuerpos neutralizantes del virus y provocar así una protección completa ante un desafío(19). El análisis del Western blot mostró la correcta expresión de la glicoproteína tanto en maíz como en baculovirus. Sin embargo, el peso molecular de la proteína recombinante expresada en el maíz fue ligeramente superior. Esto probablemente refleja diferentes modificaciones post-traduccionales, como se ha observado previamente(9). El dominio de GpRV tiene tres sitios potenciales de N-glicosilación en Asn37, Asn247 y Asn319, de los cuales los dos últimos son eficientemente glicolisados(20). En el caso de las plantas, en general, el péptido señal se escinde de acuerdo a las mismas reglas en plantas y mamíferos. Además, un precursor oligosacárido en el residuo Asn de un tripéptido Asn-X-Ser/Thr de la proteína es el mismo en las células vegetales(21). Los baculovirus glycoprotein maintains antigenic and immunogenic properties inducing virus neutralizing antibodies and thereby eliciting complete protection against challenge(19). Western blot analysis showed the correct expression of glycoprotein in both maize and baculovirus. However, the molecular weight of the recombinant protein expressed in maize was slightly higher. This likely reflects different post-translational modifications, as has been previously observed(9). The domain of GpRV has three potential N-linked carbohydrate sites at Asn37, Asn247, and Asn319, of which the latter two are efficiently core glycosylated(20). In the case of plants, in general, the signal peptide is cleaved according to the same rules in plants and in mammals. Additionally, an oligosaccharide precursor to the Asn residue of a tripeptide Asn-X-Ser/Thr of the protein is the same in plant cells(21). Baculovirus permits multiple post-translational modifications which are similar or identical to those occurring in mammalian cells, such as oligomerization, phosphorylation, glycosylation, and proteolytic cleavage(8).

The expressed $G$ protein conserved its native immunogenic properties as demonstrated by immune reactivity against a specific antiserum. Western blot analysis indicated the generation of recombinant glycoprotein rabies virus with antigenic and immunogenic properties. The results of mice immunized by im or oral dosage indicated that the presence of cytokines (IFN- $\gamma$ and IL4) results in a tendency to develop a Th1 cell response after immunization with both recombinant proteins tested, as evidenced by the detection of IFN- $\gamma$ up to $d 20$ postvaccination. Similar results were observed by Tesoro-Cruz et al $(15,22)$ using a DNA rabies vaccine and $\mathrm{Hu}$ et al(23) with a traditional vaccine with adjuvant. This result supports the hypothesis of Drings(24), who suggested that subunit vaccines (such as edible or baculovirusderived vaccines) preferentially develop a Th1 response.

However, after $15 \mathrm{~d}$, a slight increase in the concentration of IL-4, a typical cytokine of Th2 
permiten múltiples modificaciones posttraduccionales que son similares o idénticas a las que se producen en células de mamífero, tales como oligomerización, fosforilación, glicosilación y escisión proteolítica(8).

La proteína G expresada conservó sus propiedades inmunogénicas nativas, como se demostró por reactividad contra el suero hiperinmune específico. El análisis del Western blot reveló la generación de la glicoproteína recombinante del virus de la rabia con propiedades antigénicas e inmunogénicas. Los resultados de los ratones inmunizados por vía im $u$ oral indican que la presencia de citocinas (IFN- $\gamma$ e IL4) resulta en una tendencia a desarrollar una respuesta de células Th1 después de la inmunización con las dos proteínas recombinantes ensayadas, como se evidencia por la detección de IFN- $\gamma$ hasta 20 días después de la vacunación. Resultados similares se observaron por Tesoro-Cruz et al $(15,22)$ utilizando una vacuna de ADN contra la rabia y $\mathrm{Hu}$ et al(23) con una vacuna con adyuvante tradicional. Este resultado apoya la hipótesis de Drings(24), que sugiere que las vacunas subunitarias (tales como vacunas comestibles o derivadas de baculovirus) preferentemente desarrollan una respuesta Th1.

Sin embargo, después de 15 días, se observó un ligero aumento en la concentración de IL-4, una citocina típica de respuesta Th2. Esta respuesta está relacionada con la presencia de anticuerpos. La detección de IL-4 fue previamente informada por Perrin et al(25) después de la administración de una vacuna de ADN desnudo contra la rabia en perros. Por otra parte se ha demostrado la producción de IFN- $\gamma$ y altos títulos de anticuerpos en ovejas vacunadas con un adenovirus recombinante y con una vacuna comestible que expresa $\operatorname{GpVR}^{(2)}$.

La inmunización de ratones con cada una de las proteínas recombinantes ensayadas, ya sea producida en plantas o células de insecto, indujeron anticuerpos protectores específicos cuando se administraron por vía oral o im response, was observed. This response is related to the presence of antibodies. IL-4 detection has previously been reported by Perrin et al(25) after administration of a naked DNA rabies vaccine in dogs. Moreover, the production of IFN and high antibody titres in sheep vaccinated with a recombinant adenovirus and with an edible vaccine that express the GpVR have been demonstrated(2).

Immunization of mice with each of the recombinant proteins tested, either produced in plants or in insect cells, induced protective specific antibodies when they were administered by the oral or im routes, respectively, as immunized animals were protected against challenge with a lethal dose of rabies virus. These results are consistent with those obtained in previous works in which GpRV was expressed in different plant systems(7).

In this research it was observed that the level of neutralizing antibodies is related with protection; however, these began to descend at $45 \mathrm{dpi}$. Concerning the protection assay, in the case of groups 2 and 3 , the protection levels were higher than the minimal requirement established by Mexican regulations (NOM-067ZOO-2007), in which more than 80 \% protection is sufficient for classical vaccines. The protection levels $(83 \%)$ observed in mice fed the transgenic maize expressing $\mathrm{G}$ protein may be due to partial degradation by the gastric juices, although in other cases, this effect was not observed. In this study, the challenged was at d 60 to evaluate the presence of long-term antibodies using a single dose without adjuvants or booster, as this would be very useful in livestock. Moreover, it is worth highlighting that the animals of group 2 immunized orally with maize showed a higher protection compared to group 4, which had been immunized by the same route but with baculovirus-derived protein. It is possible that this is due to the protein used in group 4 which was administered in a solution, exposing the protein to the action of both proteases and $\mathrm{pH}$ present in the gastric system, which could have degraded this protein 
respectivamente. Estos resultados son consistentes con los obtenidos en trabajos anteriores en los que GpRV se expresó en diferentes sistemas vegetales(7).

En esta investigación se observó que el nivel de anticuerpos neutralizantes se relaciona con la protección; sin embargo, estos comenzaron a descender a $45 \mathrm{dpi}$. En cuanto al ensayo de protección, en el caso de los grupos 2 y 3, los niveles de protección eran más altos que el requisito mínimo establecido por la Norma Mexicana (NOM-067-ZOO-2007), en la que se establece que más del $80 \%$ de protección es suficiente para vacunas tradicionales. Los niveles de protección (83\%) observados en los ratones alimentados con el maíz transgénico que expresa la proteína $\mathrm{G}$, puede deberse a la degradación parcial por parte de los jugos gástricos, aunque en otros casos, no se observó este efecto. En este estudio, se desafió al día 60 debido a que se quería evaluar la presencia de anticuerpos a largo plazo utilizando una dosis única sin adyuvantes o refuerzo, ya que esto sería muy útil en el ganado. Por otra parte, cabe destacar que los animales del grupo 2 inmunizados por vía oral con el maíz mostraron una protección superior en comparación con el grupo 4, que había sido inmunizado por la misma ruta pero con proteínas derivadas de baculovirus. Es posible que esto se deba a que la proteína utilizada en el grupo 4 que se administró en solución, se expuso a la acción de proteasas y pH presentes en el sistema gástrico, y podrían haber degradado esta proteína más rápido que cuando se expresa en el maíz. Este último habría servido como un protector de la proteína recombinante.

\section{CONCLUSIONES E IMPLICACIONES}

Este estudio demuestra que la proteína G derivada de células de insecto infectadas con baculovirus o de plantas protege contra un desafío letal con el virus de la rabia a un nivel similar a la de una vacuna inactivada; ambos sistemas pueden ser una buena alternativa como vacuna termoestable, lo que sería muy útil para faster than when expressed in maize. The latter would have served as a protector of the recombinant protein.

\section{CONCLUSIONS AND IMPLICATIONS}

This study demonstrates that $\mathrm{G}$ protein derived from either plant or baculovirus-infected insect cells protects against a lethal challenge with rabies virus at a level similar to that of an inactivated vaccine; both systems may be a good alternative as a thermostable vaccine, which would be very useful to prevent and control the disease in tropical and subtropical countries. Based on this evidence, it was conclude that the recombinant rabies $\mathrm{G}$ protein expressed in baculovirus promoted IFN- $\gamma$ and antibodies in a similar way to the inactivated rabies vaccine. In spite of this, mice fed with transgenic maize survived to the challenge at the same percentage than group 3. These antigens promote both Th1 and Th2 responses.

\section{ACKNOWLEDGEMENTS}

Thank to Drs. Juan Carlos Saiz, José Angel Martínez Escribano and Carmen Nuñez from INIA-Spain for their contribution to express the recombinant baculovirus. This research was supported by the Consejo Nacional de Ciencia y Tecnología (CONACyT) grant (G34635B).

End of english version

prevenir y controlar la enfermedad en los países tropicales y subtropicales. Basados en esta evidencia, se concluye que la proteína $\mathrm{G}$ de la rabia recombinante expresada en baculovirus promovió IFN- $\gamma$ y anticuerpos de una manera similar a la vacuna de rabia inactivada. A pesar de esto los ratones alimentados con maíz transgénico sobrevivieron al desafío en el mismo porcentaje que en el grupo 3. Estos antígenos promueven las respuestas Th1 y Th2. 


\section{AGRADECIMIENTOS}

Se agradece a los Drs. Juan Carlos Saiz, José Ángel Martínez Escribano y Carmen Núñez en I NI A-España por sus contribuciones para expresar las proteínas recombinantes en el sistema de baculovirus. Esta investigación fue financiada por el Consejo Nacional de Ciencia y Tecnología (G34635B).

\section{LITERATURA CITADA}

1. Arntzen C. Plant-derived vaccines and antibodies: potential and limitations. Vaccine 2005;23:1859-1865.

2. Bouet-Cararo C, Contreras V, Fournier A, J allet C, Guilbert J M, Dubois E, et al. Canine adenoviruses elicit both humoral and cell-mediated immune responses against rabies following immunization of sheep. Vaccine 2011;29:1304-10.

3. Briggs JD, Dreesen WD, Wunner HW: Vaccines. In: Rabies. Jackson AC, Wunner HW editors. USA: Academic Press; 2002: 371-400.

4. Liu X, Yang $Y$, Sun $Z$, Chen J, Ai J, et al. A recombinant rabies virus encoding two copies of the glycoprotein gene confers protection in dogs against a virulent challenge. PLoS ONE 2014;9:e87105.

5. Paolazzi CC, Perez O, de Filippo J. Rabies vaccine. Developments employing molecular biology methods. Mol Biotechnol 1999; 11: 137-147.

6. Rojas-Anaya E, Loza-Rubio E, Olivera-Flores MT, GomezLim M. Expression of rabies virus G protein in carrots (Daucus carota). Transgenic Res 2009; 18:911-919.

7. Loza-Rubio E, Rojas-Anaya E. Vaccine production in plant systems an aid to the control of viral diseases in domestic animals: a review. Acta Vet Hung 2010;58:511-522.

8. Liu X, Wu X, Li L, Liu Z, Wang Z. Use of baculovirus expression systems for generation of virus-like particles: Success and challenges. Protein Express Purif 2013;90:104116.

9. Yusibov V, Streatfield SJ, Kushnir N. Clinical development of plant-produced recombinant pharmaceuticals: vaccines, antibodies and beyond. Hum Vaccine 2011;1:313-321.

10. Macfarlan RI, Dietzschold B, Koprowski H. Stimulation of cytotoxic T-lymphocyte responses by rabies virus glycoprotein and identification of an immunodominant domain. Mol Immunol 1986;23: 733-741.

11. Wojczyk B, Shakin-Eshleman SH, Doms RW, Xiang ZQ, Ertl HC, Wunner WH, Spitalnik, SL. Stable secretion of a soluble, oligomeric form of rabies virus glycoprotein: influence of $\mathrm{N}$ - glycan processing on secretion. Biochemistry 1995; 34: 25992609.

12. Aliahmadi A, Rahmani N, Abdollahi M. Plant derived human vaccines; an overview. Inter J Pharma 2006; (2):268-279.

13. Feria-Romero IA, Chavez-Rueda K, Orozco-Suárez S, BlancoFavela F, Calzada-Bermejo F, Chávez-Sánchez L, et al. Intranasal anti-rabies DNA immunization promotes a Th1related cytokine stimulation associated with plasmid survival time. Arch Med Res 2011;42:563-571.

14. Loza-Rubio E, Rojas-Anaya E, López J, Olivera-Flores MTJ. Induction of a protective immune response to rabies in sheep after oral immunization with transgenic maize. Vaccine 2012; 30: 5551-5556.

15. Jiménez de Oya N, Galindo I, Escribano-Romero E, Blázquez $\mathrm{AB}$, Alonso-Padilla J, Halaihel $\mathrm{N}$, et al. Expression and immunoreactivities of hepatitis $E$ virus genotype 3 open Reading frame-2 (ORF-2) recombinant proteins expressed in insect cells. Food Environmen Virol 2009; 1:77-84.

16. Dean DJ, Ablseth MK, Atanasiu. The florescent antibody test. In: Meslin FX, Kaplan MM, Koprowski $\mathrm{H}$, editors. Laboratory techniques in rabies. 4th ed. Geneva, I taly: WHO; 1996: 80-95.

17. Smith JS, Yager PA, Baer GM, Meslin FX, Kaplan MM, Koprowski H. A rapid fluorescent focus inhibition test (RFFIT) for determining rabies virus neutralizing antibody. In: Meslin FX, Kaplan MM, Koprowski H, editors. Laboratory techniques in rabies. 4th ed. Geneva, Italy: WHO; 1996:181-191.

18. Ferrer-Miralles N, Domingo-Espín J, Corchero JL, Vázquez E, Villaverde A. Microbial factories for recombinant pharmaceuticals. Microb Cell Fact 2009;24:17.

19. Gupta PK, Sharma S, Walunj S, Chaturvedi Raut AA, Patial S, Rai A, Pandey KD, Saini M. Immunogenic and antigenic properties of recombinant soluble glycoprotein of rabies virus. Vet Microbiol 2005; 108:207-214.

20. Shakin-Eshleman SH, Remaley AT, Eshleman JR, Wunner WH, Spitalnik SL. N-linked glycosylation of rabies virus glycoprotein. Individual sequons differ in their glycosylation efficiencies and influence on cell surface expression. J Biol Chem 1992; 267: 10690-10698.

21. Gomord V, Faye L. Posttranslational modifications of therapeutic proteins in plants. Curr Opin Plant Biol 2004; 7: 171-181.

22. Tesoro-Cruz E, Hernández-González R, Alonso-Morales R, Aguilar-Setién $A$. Rabies DNA vaccination by intranasal route in dogs. Dev Biol (Basel) 2006; 125:221-31.

23. Hu, X, Liu R, Zhu N. Enhancement of humoral and celular immune responses by monophosphoryl lipid A (MPLA) as an adjuvant to the rabies vaccine in $\mathrm{BALB} / \mathrm{C}$ mice. Immunobiology 2013;218:1524-1528.

24. Drings A. Towards a vaccine against the European Lyssaviruses a structural and immunological approach [PhD thesis]. Freien Universitäl Berlin. 1998.

25. Perrin $\mathrm{P}$, J acob Y, Tordo N. DNA-based immunization against Lyssaviruses. Intervirology 2000;43:302-311. 
